\title{
GENETIC DIVERSITY OF SIX DIFFERENT EGYPTIAN FORAGE CROPS BY MOLECULAR TOOLS Gad-Allaha, N. O. ${ }^{1}$; E. M. R. Metwali ${ }^{2}$; E. A. H. Mostafa ${ }^{1}$ and E.M. Zayed ${ }^{3}$ \\ 1. Genetic and Cytology National, Res. Center, Dokki, Giza, Egypt. \\ 2. Suez Canal Univ., Agric. Fac., Botany Dept., Ismailia, Egypt. \\ 3. Crops Res. Inst., Giza, Egypt.
}

\begin{abstract}
The aim of the present study was to estimate genetic variation in grass sorghum (sorghum, Tunis grass, Sudan grass) and other forage species (ray grass, pearl millet, guar). Three molecular systems i.e. isozymes-PAGE, seed protein, SDSPAGE and AFLP were used. The results indicated the presence of high similarity matrix among sorghum and ray grass; pearl millet and Sudan grass (100\%) and low similarity matrix among guar and sorghum; guar and Tunis grass (44.4\%) in peroxidase analysis, where the total bands was 21 with $100 \%$ polymorphism and without any unique bands. This data was different comparing with superoxidase dismutase, protein and AFLP analysis. On the other hand, the combined set data of three molecular system revealed that Tunis grass have similarity matrix in a value of $(70.6 \%)$ with sorghum and $(90.7 \%)$ with Sudan grass.

Also, Tunis grass gave similarity matrix of $(89.7 \%),(87.9 \%)$ and $(71.2 \%)$ with ray grass, pearl millet and guar, respectively. In cluster analysis with combined data set, Tunis grass was located in sub cluster 1 with sudan grass and pearl millet in the same group, and in the same cluster of ray grass. The different clusters were found between Tunis grass, sorghum and guar. Tunis grass did not give any unique bands with all analysis but sorghum, guar and ray grass gave unique bands with protein and AFLP analysis.

Keywords: Forage crops, sorghum, diversity, molecular profile, Cluster analysis
\end{abstract}

\section{INTRODUCTION}

Grass sorghums include Sudan grass and Tunis grass are annuals and grow quickly and are generally used for summer pasture. Johnson grass, a perennial grass sorghum, is considered a pest when it is out of control, however, it makes an excellent hay for cattle feed. For human consumption sorghum is used for its grain and a syrup depending on the type grown. Sorghum is considered to be a native to tropical Africa, continues to be a leading cereal grain in the most areas of the continent, and is a major staple food and fodder crop grown worldwide, with an annual average production of 61 million tones over the past decade (FAO, 2005). Moreover, according to FAO, sorghum ranks fifth in world grain production behind wheat, rice, maize, and barley.

Sorghum (Sorghum bicolor ssp. bicolor) as a traditional cultivars were classified by Harlan and De Wet (1972) into five main races (bicolor, caudatum, durra, guinea, kafir) and 10 intermediates (e.g. bicolor-caudatum, durra-kafir), mainly on the basis of spike let and grain morphology. Snowden (1936) defined 7 weedy, 13 wild, and 28 cultivated species and numerous varieties and forms from within this variability. A refinement of Snowden's 
Gad-Allaha, N. O. et al.

classification was developed by Jakuševskij (1969) and is still used in some parts of the world (Fritsch et al., 2001). De Wet and Huckabay's (1967) classification of $S$. bicolor separated the perennial plants as "S. bicolor subsp. halepense"; from the annual plants of this complex where they were combined into $S$. bicolor subsp. bicolor, treating the cultivated members as $S$. bicolor var. bicolor and partitioning the wild and weedy relatives into three varieties, S. bicolor vars. "arundinaceum", "aethiopicum", and "verticilliflorum" (Piper, 1915). For the same reason as before, these varietals names were also not validly published. To these three varieties, assumed to have been established by De Wet et al. (1970) was added a fourth, "S. bicolor var. virgatum (Hack.) as well as "S. virgatum (Hack.) Stapf according to John and Jeff (2007). In Egypt, Tunis grass is a new forage crop and it was identified by the Egyptian flora and Phytotaxonomy Research Department, Agriculture Museum, Dokki, Giza, Egypt. It has a high fresh and dry yield with follow condition, cutting in $120 \mathrm{~cm}$ and fertilized $80.2 \mathrm{~kg} \mathrm{~N}$ per hectare for three cuts Abdel-Aziz and Abdel-gwad (2008).

In sorghum breeding and genomic resources are less than the other major cereals as rice, wheat, maize and barley according to economic values. However, when interest has focused on the crop due to its drought resistance and small genome size $(\sim 760 \mathrm{Mb})$ compared to close relatives maize ( 2500 $\mathrm{Mb}$ ) and sugarcane (2550 to $4200 \mathrm{Mb}$ ). In recent years, the potential of sorghum as a biofuel crop has led to additional investment culminating in the sequencing of the sorghum genome (Bowers et al., 2007). Many molecular marker technologies have been developed and applied to studying patterns of genetic diversity in grass sorghums germplasm collections and in breeding programs (Ferreira, 2005) and Kawar et al. (2009). Progress in sorghum characterization of the transcriptome has been paralleled by identification of differential gene expression in response to biotic and a biotic factors, including green bug feeding Park et al. (2006). Pratibha Brahmi et al. (2004) analyzed the genetic diversity in cultivated guar using allozyme polymorphism and compare it with reported morphological diversity. As well as, Lamy et al. (1994) are using pearl millet molecular markers to follow the introgression of genomic segments from the wild progenitors of this crop into several populations based on crosses of wild and cultivated accessions from various parts of western and central Africa. Finally, Ruby Tiwari, et al. (2009) established allergenic cross reactivity between the members of the Pooids (Lolium perenne, Phleum pratense, and Poa pratensis) and Chloridoids (Cynodon dactylon and Paspalum notatum). In the present study, the variation of grass sorghum and other forge species were estimate by molecular tools.

\section{MATERIALS AND METHODS}

\section{Plant Materials}

This work was carried out in collaboration between the Agricultural Research Center, Field Crops Research Institute, Forage crops research department; National Research Centre, Division of Genetic Engineering and Botany Department, Faculty of Agriculture, Suez Canal University, during two 
years 2009 and 2010. Seeds of different six Egyptian forage crops have been obtained from Forage Crops Research Department, Field Crops Research Institute, Agricultural Research Center, Giza, Egypt. The list of these forage crops is presented in Table I.

Table 1: The common and botanical name, Chromosome number, wild type, season and Egyptian location.

\begin{tabular}{|l|l|l|l|c|c|c|}
\hline \multirow{2}{*}{ No } & \multicolumn{1}{|c|}{$\begin{array}{c}\text { Common } \\
\text { name }\end{array}$} & \multicolumn{1}{|c|}{ Botanical name } & $\begin{array}{c}\text { Chromosome } \\
\text { number } \\
\text { Somatic cells } \\
\text { polyploidy }\end{array}$ & $\begin{array}{c}\text { Wild } \\
\text { type }\end{array}$ & Season & $\begin{array}{c}\text { Egypt } \\
\text { Iocation }\end{array}$ \\
\hline 1 & Sorghum & Sorghum bicolor & 20 & imported & Summer & all \\
\hline 2 & Sudan grass & $\begin{array}{l}\text { Sorghum vulgare } \\
\text { sudanense }\end{array}$ & $20^{* *}$ & found & Summer & all \\
\hline 3 & Tunis grass & Sorghum virgatum & 20 & found & Perennial & north \\
\hline 4 & Ray grass & Lolium multiflorum & 14 & imported & Winter & north \\
\hline 5 & Pearl millet & Pennisetum glaucum & $14^{\#}$ & imported & Summer & all \\
\hline 6 & Guar & Cyamopsis tetragonoloba & $14^{\# \#}$ & found & Summer & upper \\
\hline
\end{tabular}

**Kim et al.(2005), * Ahloowalia (1965),\# Techio et al.(2006) \#\# Bewal et al.(2009)

\section{Isozyme Analysis}

Isozymes extraction from the six cultivars by homogenizing $0.5 \mathrm{~g}$ fresh leaves and roots samples in $1 \mathrm{ml}$ extraction buffer (10\% glycerol) using a mortar and pestle. The extract was then transferred into clean eppendorf tubes and centrifuged at $10000 \mathrm{rpm}$ for 5 minutes according to Stegemann et al. (1985b). The supernatant was transferred to new clean eppendorf tubes and kept at $-20{ }^{\circ} \mathrm{C}$ until needed for electrophoretic analysis. A volume of 40 $\mu \mathrm{l}$ extract of each sample was mixed with $20 \mu \mathrm{l}$ sucrose and $10 \mu \mathrm{l}$ bromophenol blue, then a volume of $50 \mu \mathrm{l}$ from this mixture was applied to each well. The run was performed at 150 volt until the bromophenol blue dye reached the separating gel and then the voltage was increased to 200 volt. Electrophoresis apparatus was placed inside a refrigerator during running duration. After electrophoresis, the gels were stained according to their enzyme systems with the appropriate substrate and chemical solutions, and then incubated at room temperature in dark for complete staining for about 1 to 2 hours. Gel was placed into this solution and 5 drops of hydrogen peroxide was added. The gel was incubated at room temperature until bands appear (Brown, 1978).

\section{Protein Analysis}

Sodium dodecylsulfate polyacrylamide gel electrophoresis (SDSPAGE) was used to study the banding patterns of the six cultivars. Protein fractionation was performed on vertical slab $(16.5 \mathrm{~cm} \times 18.5 \mathrm{~cm} \times 0.2 \mathrm{~cm})$ Hoefer E600, Amersham Pharmacia biotech. According to the method of Laemmli (1970) as modified by Studier (1973), Sample extraction buffers (Tris-HCl buffer, pH 7.5) (Jonathan and Weaden, 1990) and Staining solution Coomassie briliant blue-R250 staining solution was well mixed and kept at room temperature in a dark bottle.

The lower buffer tank was filled with running buffer and attached with upper buffer tank, so that the gels were completely covered. Gels were distained with $350 \mathrm{ml}$ distaining solution. The distaining solution was changed 
Gad-Allaha, N. O. et al.

several times until the gel background was clear. The electrodes were connected to a power supply and adjusted at $100 \mathrm{~V}$ until the bromophenol blue dye reached the resolving gel. The voltage was Increased to $250 \mathrm{~V}$ until the bromophenol blue reached near the bottom of the resolving gel. Gels were photographed using a $35 \mathrm{~mm}$ color film (200 ASA) and scanned with Bio-Rad Video Densitometer Model 620 USA, at a wavelength of 577.

Software data analysis for Bio-Rad Model 620 densitometerand computer was used as recommended by the manufacturer. The frequency of two isozymes, protein among 6 forage crops genotypes was calculated based on the presence of band as ' 1 ' or absence of band as ' 0 ' (Sokal and Rohlf, 1995). The genetic associations between varieties were evaluated by calculating the Jaccard similarity coefficient for pair-wise comparisons based on proportion of shared band

\section{Aflp Analysis}

DNA preparation, used in this study are described in details in (Pažoutová et al., 2000b, 2002a). AFLPs were generated as described by Zeller etal. (2000) and Vos et al. (1995). Genomic DNA (100 ng) was digested by EcoRI and Msel and ligated to adapters, pre amplified using primers EcoRI-core (CTCGTAGACTGCGTACCAATTC) and Msel-core (GACGATGAGTCCTGAGTAA) and amplified with final amplification primer pairs EcoRI + AG/Msel + C (Tooley et al., 2000), EcoRI + TT/Msel + AC, and $\mathrm{EcoRI}+\mathrm{GG} / \mathrm{Msel}+\mathrm{CT}$. EcoRl primer were used and fragments were separated in $6 \%$ polyacrylamide gel (Long Ranger FMC, USA). Polymorphic AFLP fragments were scored as binary characters for each genotype. A distance matrix of genotypes was calculated for both fingerprinting methods according to $\mathrm{Nei}$ and $\mathrm{Li}$ (1979) with 500x bootstrapping, and a dendrogram was constructed using the unweighted pair group method with arithmetic mean (UPGMA) as implemented in TREECON 1.3b (Van de Peer and De Wachter, 1997).

\section{RESULTS AND DISCUSSION}

\section{Isozyme Analysis}

Six different forage crop species were studied by Peroxidase (Pox) and Total superoxide dismutase (Sod).

\section{Peroxidase isozymes (Pox):}

The results revealed 21 bands from peroxidase isozymes without any monomorphic which made polymorphism $100 \%$ as shown in Table 7 and Figure 1. The data in Table 2 explained the Similarity matrix among six different Egyptian forage crops which were demonstrated the value among sorghum and Tunis grass is $33.3 \%$, the same value between ray grass and Tunis grass. Moreover, two values of: $(75.0 \%)$ and $(40.0 \%)$ were given among pearl millet, sorghum, Tunis grass and ray grass and also between guar and the same plants, respectively. Sudden grass gave the same similarity matrix value of pearl millet of $(75.0 \%)$. Guar gave $(57.1 \%)$ with peal millet and Sudden grass. The high similarity matrix value (100\%) was given among ray grass and sorghum, pearl millet and Sudden grass in peroxidase 
analysis. Ke ming et al. (1995) found that presence or disappearance of some peroxidase and esterase isozyme bands was related to wounding. Some isoperoxidase bands disappeared at the time of vascular tissue formation. Marie and Harold (1971) found that each species pattern was unique, and no single peroxidase band was common to all the species. Based on considerations of interspecific cross compatibility and chromosomal rearrangements the taxonomic division of the genus into three sections was further subdivided to give five groups. Jean et al. (1971) have demonstrated that peroxidase was a single polypeptide chain and that subunit association was not involved in the isoenzyme system. On the basis of tryptic peptide maps, it was apparent with the peroxidase isozymes. Isozymes within a group appeared to possess very similar primary structures. Whether more than one gene is involved in their biosynthesis cannot be ascertained at present. The catalytic properties of the isozymes followed an identical pattern.

So, the genetic variation among six species in peroxidase activity due to more than one gene is involved in their biosynthesis and chromosomal rearrangements.

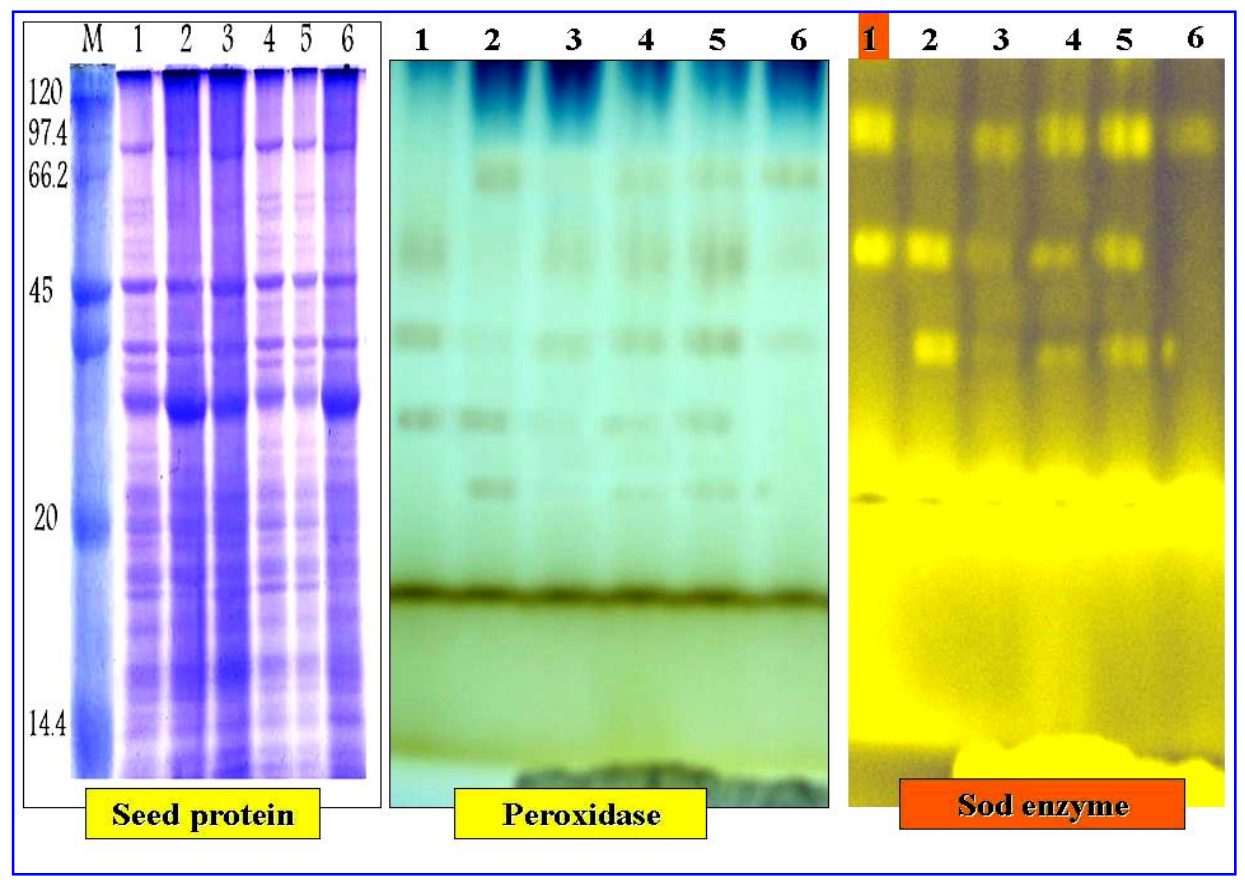

Figure 1: Isozymes (Peroxidase and Total superoxide dismutase (Sod)) and seed protein analysis of six different Egyptian forage crops (lane 1 in seed protein : M. marker; 1- 6 in seed protein , peroxidase, and Sod isozymes sorghum [Tunis grass, Ray grass, Pearl millet, Sudan grass and Guar]. 
Gad-Allaha, N. O. et al.

Table 2: Similarity matrix among six different Egyptian forage crops were used based on peroxidase analysis.

\begin{tabular}{|l|c|c|c|c|c|}
\hline \multicolumn{5}{|c|}{ Case } & \multicolumn{5}{c|}{ Matrix File Input } \\
\cline { 2 - 6 } \multicolumn{1}{|c|}{ Tunis grass } & Ray grass & Pearl millet & Sudan grass & Guar \\
\hline Sorghum & 33.3 & 100.0 & 75.0 & 75.0 & 40.0 \\
\hline Tunis grass & & 33.3 & 75.0 & 75.0 & 40.0 \\
\hline Ray grass & & & 75.0 & 75.0 & 40.0 \\
\hline Pearl millet & & & & 100.0 & 57.1 \\
\hline Sudan grass & & & & & 57.1 \\
\hline
\end{tabular}

\section{Superoxide dismutase isozyme (Sod):}

The results in total superoxide dismutase (Sod) activity gave 15 bands as a total bands which were divided into 6 bands monomorphic and 9 polymorphic in $60 \%$ polymorphism as shown in Table 7 and Figure 1. In Table 3 , it revealed that guar forage crops have the same similarity matrix value $(50 \%)$ with Tunis grass, ray grass, pearl millet and Sudden grass. This value is lowest value among six forage crops.

Table 3: Similarity matrix among six different Egyptian forage crops were used based on superoxide dismutase analysis.

\begin{tabular}{|l|c|c|c|c|c|}
\hline \multirow{2}{*}{ Case } & \multicolumn{5}{|c|}{ Matrix File Input } \\
\cline { 2 - 6 } & Tunis grass & Ray grass & Pearl millet & Sudan grass & Guar \\
\hline Sorghum & 80.0 & 80.0 & 80.0 & 80.0 & 66.7 \\
\hline Tunis grass & & 1.000 & 100.0 & 100.0 & 50.0 \\
\hline Ray grass & & & 100.0 & 100.0 & 50.0 \\
\hline Pearl millet & & & & 100.0 & 50.0 \\
\hline Sudan grass & & & & & 50.0 \\
\hline
\end{tabular}

The highest value $100 \%$ was repeated among Sudden grass with Tunis grass, ray grass and pearl millet; pearl millet with tunis grass and ray grass; ray grass with tunis grass. The result of Wang et al. (2006) showed an obvious and stable variation in the isozyme phenotypes in two different pearl oyster species. The SOD and EST isozymes from gill and MDH, ME and G6PDH from adductor muscle were species-specific. The electrophoretograms of these isozymes could be used as markers to differentiate the two pearl oysters. Li et al. (1995) reported that the banded characters at EST-1, SOD-1, SOD-2, and SOD3a loci may be used as biochemical markers to identify the $R$. kamoji chromosomes carrying these loci in a $T$. aestivum $\times R$. kamoji hybridization program. The lowest similarity with the rest of the species was in accord with the morphological studies (Khatamsaz, 1998) and other numerical taxonomic works (Sneath, and Sokal, 1973), (Pooler Simon, 1993) and (Sheidai et al., 2000) So, the considerable molecular diversity which could be found among six forage crops were obvious by isozymes Sod. 


\section{Seed protein analysis (SDS-PAGE):}

The results show that the protein gave 25 bands in total 111 bands for all forage crops from 113- $11 \mathrm{KDa}$. In Table 7, Data revealed 66 bands monomorphic, 45 bands polymorphic and $40.5 \%$ polymorphism. The unique bands were found in $28 \mathrm{KDa}$ by ray grass, $63 \mathrm{KDa}$ by sorghum and $138 \mathrm{KDa}$ by guar as advantage for this forage crops. In Table 4, high similarity matrix was found to be $94.7 \%$ between pearl millet and ray grass, also the same ratio between ray grass and Tunis grass.

Table 4 : Similarity matrix among six different Egyptian forage crops were used based on seed protein analysis.

\begin{tabular}{|l|c|c|c|c|c|}
\hline \multicolumn{5}{|c|}{ Proximity Matrix } \\
\hline \multirow{2}{*}{ Case } & \multicolumn{5}{c|}{ Matrix File Input } \\
\cline { 2 - 6 } & Tunis grass & Ray grass & Pearl millet & Sudan grass & Guar \\
\hline Sorghum & 70.6 & 66.7 & 64.7 & 74.3 & 83.3 \\
\hline Tunis grass & & 94.7 & 94.4 & 91.9 & 78.9 \\
\hline Ray grass & & & 94.7 & 92.3 & 80.0 \\
\hline Pearl millet & & & & 91.9 & 78.9 \\
\hline Sudan grass & & & & & 82.1 \\
\hline
\end{tabular}

On other hand, the tunis grass and sorghum have the lowest value of $70.6 \%$. while it gave $91.9 \%$ with sudden grass, $94.4 \%$ with pearlmillet, $94.7 \%$ with ray grass and 78.9 with guar.

\section{AFLP Analysis:}

AFLP genetic relatedness among different six forage crops ;one primer combinations produced a total of 172 scored bands for the 106 polymorphic bands, 66 monomorphic bands and $61.6 \%$ polymorphism which reflects the ability of system to be different among materials under study. As well as, the unique bands which appeared in guar and sorghum as follow 290bp, 810bp, 210bp and 660bp, respectively (Figure 2 and Table 7). Moreover, similarity matrix among six different Egyptian forage crops revealed that the highest similarity was $91.2 \%$ among tunis grass and ray grass as well as tunis grass and sudden grass followed by sudden grass and ray grass. In this respect, the lowest similarity was $69.1 \%$ between guar and pearl millet followed by $70.2 \%$ between guar and Tunis grass Table 5 .

The dendrogram would explain the differences among the six different Egyptian forage crops which had the same sprite in protein and AFLP systems as shown in Fig. 3.

The dendrogram based on AFLP, Figure 3, one primers divided into two main clusters distribution of the six different Egyptian forage crops, sorghum and Guar were placed in the cluster 1, while, the second cluster involved the rest of Egyptian forage crops. The second cluster subdivided further into subclusters. The first subcluster included sudden grass only. The second subcluster included Tunis grass, Ray grass and Pearl millet. 
Gad-Allaha, N. O. et al.

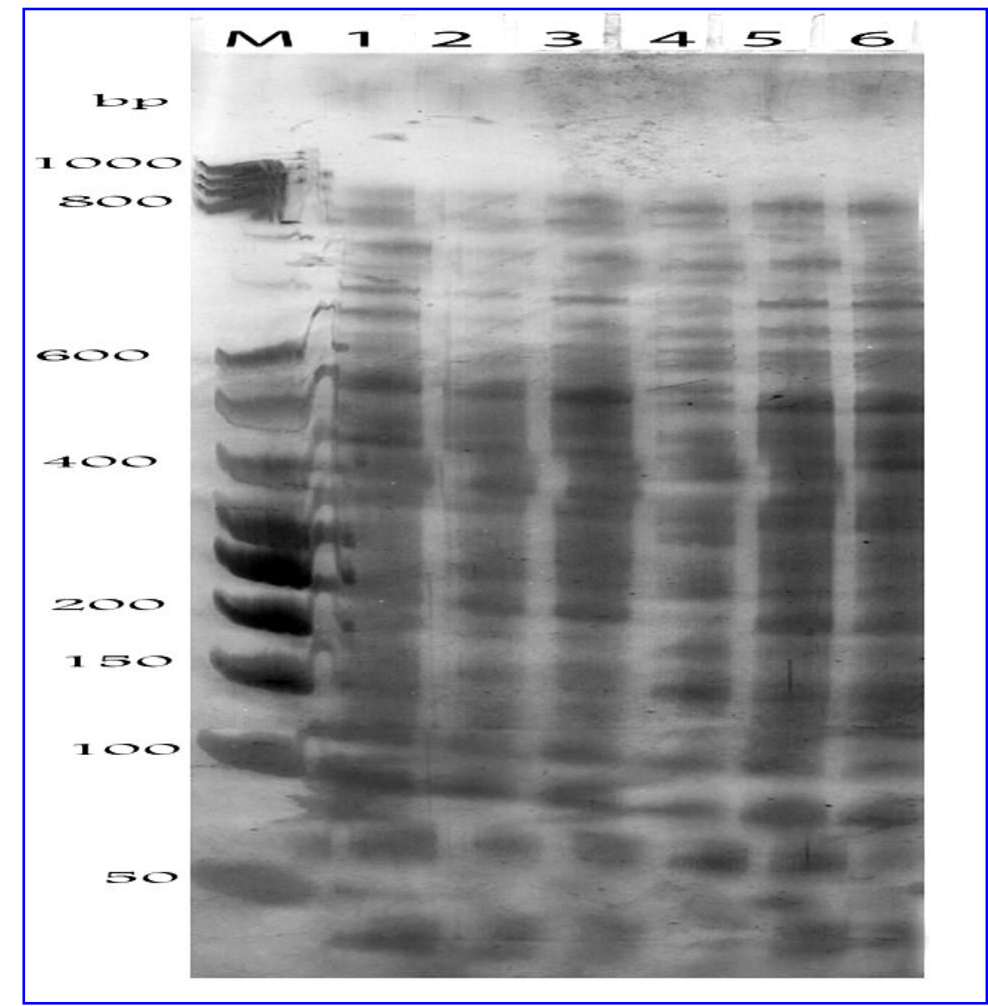

Figure 2: Analysis of six different Egyptian forage crops by AFLP; lane 1 in AFLP: M. marker;1- 6 in AFLP gel: sorghum, Tunis grass, Ray grass, Pearl millet, Sudan grass and Guar.

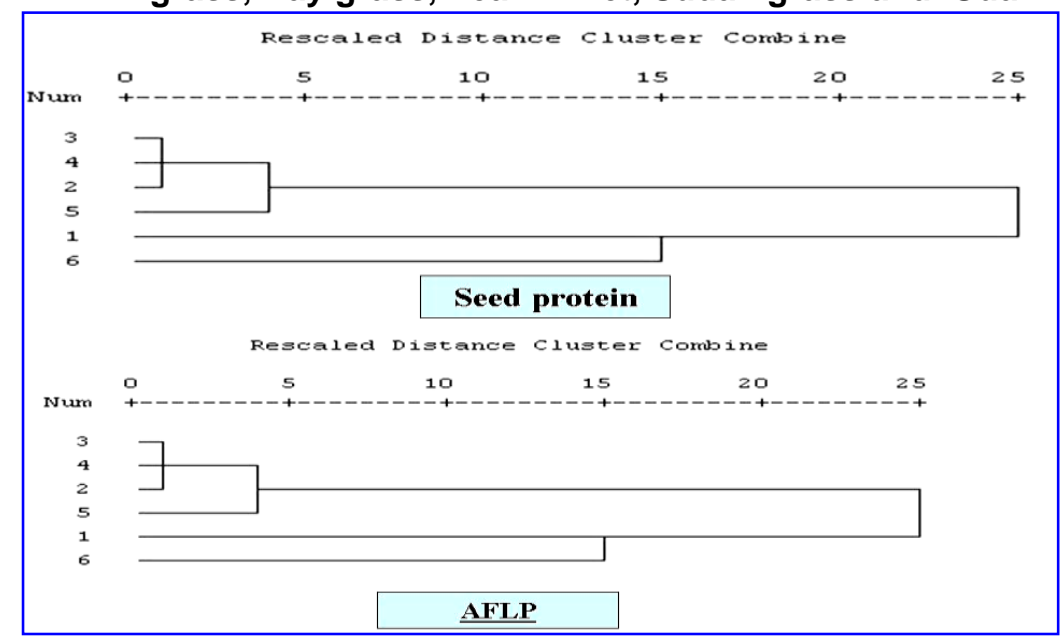


Figure 3: Cluster analysis of the seed protein and AFLP data in case of the of six different Egyptian forage crops; 1- 6: Sorghum, Tunis grass, Ray grass, Pearl millet, Sudan grass and Guar.

Table 5: Similarity matrix among six different Egyptian forage crops were used based on AFLP analysis.

\begin{tabular}{|l|c|c|c|c|c|}
\hline \multirow{2}{*}{ Case } & \multicolumn{5}{c|}{ Matrix File Input } \\
\cline { 2 - 6 } & Tunis grass & Ray grass & Pearl millet & Sudan grass & Guar \\
\hline Sorghum & 73.7 & 73.3 & 65.5 & 80.0 & 80.0 \\
\hline Tunis grass & & 91.2 & 88.5 & 91.2 & 70.2 \\
\hline Ray grass & & & 83.6 & 90.0 & 73.3 \\
\hline Pearl millet & & & & 87.3 & 69.1 \\
\hline Sudan grass & & & & & 76.7 \\
\hline
\end{tabular}

Combined data: The data in Table 6 and Figure 4 showed the genetic relationships among six different Egyptian forage crops as follow:

Table 6: Similarity matrix among six different Egyptian forage crops were used based on peroxidase, SOD, seed protein and AFLP analysis.

\begin{tabular}{|l|c|c|c|c|c|}
\hline \multicolumn{5}{|c|}{ Proximity Matrix } \\
\hline \multirow{2}{*}{ Case } & \multicolumn{5}{c|}{ Matrix File Input } \\
\cline { 2 - 6 } & Tunis grass & Ray grass & Pearl millet & Sudan grass & Guar \\
\hline Sorghum & 70.6 & 72.9 & 66.7 & 77.8 & 78.8 \\
\hline Tunis grass & & 89.7 & 90.2 & 90.7 & 71.2 \\
\hline Ray grass & & & 87.9 & 90.3 & 73.4 \\
\hline Pearl millet & & & & 90.7 & 71.2 \\
\hline Sudan grass & & & & & 76.4 \\
\hline
\end{tabular}

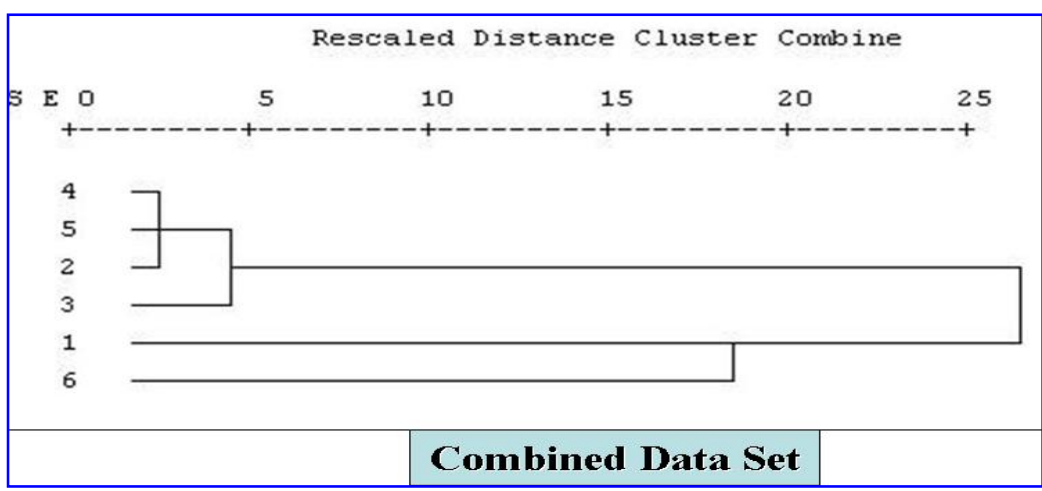

Fig. 4: Cluster analysis of the based on peroxidase, SOD, seed protein and AFLP analysis data in case of the of six different Egyptian forage crops;1- 6: 1=Sorghum, 2=Tunis grass, 3=Ray grass, 4 = Pearl millet, $5=$ Sudan grass and $6=$ Guar. 
Gad-Allaha, N. O. et al.

The similarity matrix among six different Egyptian forage crops were revealed a high similarity of $90.7 \%$ among Sudan grass and tunis grass as well as Sudan grass and pearlmillet followed by $90.3 \%$ for Sudan grass and ray grass. While, the lowest similarity of $70.6 \%$ was found between Tunis grass and sorghum followed by $71.2 \%$ between guar and Tunis grass as seen in Table 6. The dendrogram based on all systems in this study shown Figure 4, it divided the crops into two main clusters distribution of the six different Egyptian forage crops, sorghum and guar were placed in the cluster 1, while, the second cluster involved the rest of Egyptian forage crops. The second cluster subdivided further into subclusters. The first subcluster includes Sudan grass only and the subcluster two was distributed Tunis grass, Ray grass and Pearl millet. This could agree with the Indian gene centre possesses a rich genetic diversity in native grasses and legumes. There are reports of 245 genera and 1,256 species of Gramineae of which about 21 genera and 139 species are endemic. One-third of Indian grasses are considered to have fodder value. Most of the grasses belong to the tribes Andropogoneae (30\%), Paniceae (15\%), and Eragrosteae (9\%). Similarly, out of about 400 species of 60 genera of Leguminosae, 21 genera are reported to be useful as forage. The main centers of genetic diversity are peninsular India (for tropical types) and North-Eastern Region (for sub-tropical types) besides some micro-centres for certain species (forage and grasses, 2008). The data in Table 7 illustrate the efficient of marker systems species diversity. AFLP system give the highest total number of bands 172 followed by protein 111 bands as total bands; while the lowest total bands in isozymes SOD followed by peroxidase enzyme 11 and 15 bands respectively. The polymorphic bands were highest in the AFLP followed by protein and Peroxidase with values, 105,45 and 21 respectively. While, the polymorphism percentage were highest in peroxidase with value $100 \%$ followed by AFLP and isozymes SOD with values 61.6 and 60 , respectively.

Furthermore, the unique bands in Table 7 of sorghum, ray-grass and guar from all species had the unique bands which could differ from one specie to others. The isozymes in both peroxidase and SOD could not gave the unique band. The protein and AFLP could appeared unique bands. Sorghum species had two bands in AFLP with molecular weight 210 and 660 $\mathrm{bp}$, as well as bands in protein which appeared in $63 \mathrm{kDa}$. On the other hand, guar was appeared to have three bands with values 810 and 290 in AFLP system and $138 \mathrm{kDa}$ with protein system. Finally ray-grass gave one unique band in protein system which has $29 \mathrm{kDa}$.

Table 7: Levels of polymorphism and unique varieties-specific bands and status of it based on peroxidase, SOD, seed protein SDSPAGE and AFLP analysis.

\begin{tabular}{|l|c|c|c|c|c|c|}
\hline \multirow{2}{*}{ No. } & \multirow{2}{*}{$\begin{array}{c}\text { Total } \\
\text { bands }\end{array}$} & $\begin{array}{c}\text { Polymorphic } \\
\text { band }\end{array}$ & $\begin{array}{c}\text { Monomorphic } \\
\text { band }\end{array}$ & $\begin{array}{c}\text { Polymorphism } \\
\%\end{array}$ & \multicolumn{2}{c|}{ Unique bands } \\
\cline { 5 - 7 } & & 21 & 0 & 100 & Genotypes & MW \\
\hline POX & 21 & 21 & 6 & 60 & - & - \\
\hline SOD & 15 & 9 & 66 & 40.5 & Ray grass & $29 \mathrm{kDa}$ \\
\hline Protein & 111 & 45 & & Guar & $138 \mathrm{kDa}$ \\
\hline \multicolumn{7}{|r|}{} \\
\cline { 5 - 7 }
\end{tabular}


J.Agric. Chem. and Biotechn., Mansoura Univ. Vol. 2 (7), July, 2011

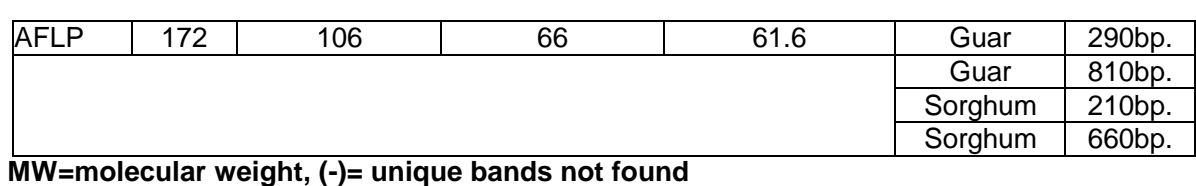

$M W=$ molecular weight, $(-)=$ unique bands not found 


\section{REFERENCES}

Abdelaziz, T. K. and M.A.S. Abdel-gwad 2008.Yield and quality of tunis grass as affected by plant height at cutting and $\mathrm{N}$ fertilizer. Ain shams university ,cairo 53(1):157-169.

Ahloowalia, B.S. 1965. A root tip squash technique for screening chromosome number in Lolium. Euphytica 14:(2)70-72.

Bewal, S., Jigyasa PUROHIT, Arun KUMAR, Rajkumari KHEDASANA, Satyawada Rama RAO(2009). Cytogenetical Investigations in Colchicine-induced Tetraploids of Cyamopsis tetragonoloba L. Czech J. Genet. Plant Breed., 45 (4): 143-154.

Bowers, J.E., Rokhsar, D.S. and Paterson, A.H. 2007. Update on the sorghum (Sorghum bicolor) genome sequence. Plant and Animal Genomes XV Conference: 13-17 January. San Diego.

Brown, A.H.D. 1978. Isozymes, plant population genetic structure and genetic conservation. Theoretical Applied Genetic 52: 145-157.

De Wet, J.M.J. and Huckabay, J.P. 1967. The origin of Sorghum bicolor. II. Distribution and domestication. Evolution 21:787-802.

De Wet, J.M.J., Harlan, J.R. and Price, E.G. 1970. Origin of variability in the Spontanea complex of Sorghum bicolor. American Journal of Botany 57: 704-707.

FAO (Food and Agriculture Organization of the United Nations).2005. FAOSTAT Database. FAO, Rome.

Ferreira, M. E. 2005. Molecular analysis of gene banks for sustainable conservation and increased use of crop genetic resources. The Role of Biotechnology Villa Gualino, Turin, Italy - 5-7 March.

Forage and grasses 2008. www.icar.org.in/files/forage-and-grasses. Forage crops grown and their area and productivity in India.

Fritsch, R., Specht, C.E., Hanelt, P., et al. 2001. Gramineae (Poaceae). Pp. 2436-2750 in: Hanelt, P. (ed.), Mansfeld's Encyclopedia of Agricultural and Horticultural Crops (Except Ornamentals). Springer-Verlag, Berlin.

Harlan, J.R. and De Wet, J.M.J. 1972. A simplified classification of cultivated sorghum. Crop Science 12: 172-176.

Jakuševskij, E.S. 1969. Vidovoj sostav sorgo i ego selekcionnoe izpol'zovanie [Varietal composition of sorghum and its use for breeding]. Trudy Prikl. Bot. 41: 148-178.

Jean H. C., Leland M. S., Ernest K. et al. 1971. Peroxidase Isoenzymes from Horseradish Roots. The journal of Biological Chemistry 14: 4546-4551

John, H.W. and Jeff, D. 2007. The nomenclature of Sorghum bicolor (L.) Moench (Gramineae). TAXON 56 (3) :941-946

Jonathan, F.W. and Weaden N.F. 1990. Visualization and interpretation of plant isozymes In: Soltis, D.E. and P.S. Soltis, (eds) isozymes in plant Biology, London Champan and Hall. 5-45.

Ke-ming, C., Zhong-ming, Z., Ju-huai, L. et al. 1995. Changes of peroxidase, esterase isozyme activities and some cell inclusions in regenerated vascular tissues after girdling in Broussonetia papyrifera (L.) Vent. Trees - Structure and Function 9 (3): 165-170. 
Kawar P.G., Devarumath M.R., Nerkar Y. 2009.Used of RAPD markers for assessment of genetic diversity of sugar cane cultivars. Indian Journal of Biotechnology 8:67-71.

Khatamsaz, M. 1998. Flora of Iran (Solanaceae). Research Institute of Forests and Rangelands, Tehran.

Kim, Jeong-Soon, Patricia E. Klein, Robert R. Klein, H. James Price, John E. Mullet, David M. Stelly 2005. Chromosome Identification and Nomenclature of Sorghum bicolor Genetics169(2): 1169-1173.

Laemmli, U.K. 1970. Cleavage of structural proteins during the assembly of the head of bacteriophage T4. Nature 227: 680-685.

Lamy, F., E. Martel, A. Ricroch, T. Robert, and A. Sarr. 1994. An integrated strategy, including the use of RFLP markers, to optimise the use of genetic resources of the primary gene pool of pearl millet. p. 86-89 in J.R. Witcombe and R.R. Duncan (eds.): Use of molecular markers in sorghum and pearl millet breeding for developing countries. Overseas Development Administration: London, U.K.

Li-Hui, L., Richard, R., Wange, C. et al. 1995. Isozyme analysis of three species of of Roegneria C. Koch from China . Genetic Resources and Crop Evolution 42(2):119-125.

Marie E. C. and Harold H. S. 1971. Peroxidase Isozymes: A Measure of Molecular Variation in Ten Herbaceous Species of Datura .American Journal of Botany 58(7): 688-696

Nei, M. and Li, W.H. 1979. Mathematical model for studying genetic variation in terms of restriction endonucleases. Proceedings of the National Academy of Sciences, USA 76, 5269-73.

Park, S.J., Huang, Y., and Ayoubi, P. 2006. Identification of expression profiles of sorghum genes in response to greenbug phloem-feeding using cDNA subtraction and microarray analysis. Planta 223(5): 932 pages.

Pažoutová, S., Johnson, N., Kolařík, M, et al. 2002a. Heteropogon triticeusa new host for Claviceps sorghi in India. Journal of Phytopathology 150: 1-4.

Pažoutová, S., Raybould, A.F., Honzátko, A. et al. 2002b. Specialised population of Claviceps purpurea from salt marsh Spartina species. Mycological Research 106: 210-4.

Piper, C.V. 1915. Andropogon halepensis and Andropogon sorghum. Proc. Biol. Soc. Wash. 28: 25-44.

Pooler, M.R. and P.W. Simon. 1993. Characterization and classification of isozyme and morphological variation in a diverse collection of garlic clones. Euphytica 68: 121-130.

Pratibha Brahmi, K.V. Bhat and A.K. Bhatnagar 2004. Study of allozyme diversity in guar [Cyamopsis tetragonoloba (L.) Taub.] germplasm . Genetic Resources and Crop Evolution Volume 51, Number 7, 735746.

Ruby Tiwari, Prem L Bhalla and Mohan B Singh 2009. Evaluation of Molecular Basis of Cross Reactivity between Rye and Bermuda Grass Pollen Allergens. Allergology International. 58:557-564. 
Sheidai, M., M. Khatamsaz and M. Mosallanejad. 2000. Numerical taxonomy and seed protein analysis of Hyoscyamus species in Iran. J. Sci. I.R. Iran, 112: 83-91.

Sneath, P.H. and R.R. Sokal. 1973. Numerical Taxonomy. Freeman, San Francisco

Snowden, J.D. 1936. The Cultivated Races of Sorghum. Adlard \& Son, Ltd., London.

Sokal, R. and Rohlf, F.J. 1995. Biometry, 3rd edn. New York, USA: W.H. Freeman.

Stegemann, H., W. Burgerneister, H. Franksen and E. Krojerreckenfort, 1985b. Polyacrylamid gel electrophoresis manual, Ch.3, p.6 and Ch.5, p.1.

Studier, F. W. 1973. Analysis of bacteiophage T7 early RNAs and proteins of slab gels. Journal of Molecular Biology 79: 237 -24.

Techio, V.H., Lisete Chamma Davide, Antônio Vander Pereira 2006. Meiosis in elephant grass (Pennisetum purpureum), pearl millet (Pennisetum glaucum) (Poaceae, Poales) and their interspecific hybrids. Genetics and Molecular Biology 29 (2): 353-362

Tooley, P.W., O'Neill, N.R. and Goley, E.D. 2000. Use of random amplified microsatellites and AFLPs in assessing phenotypic diversity among isolates of Claviceps africana and other Claviceps species. Phytopathology 90: 1126-30.

Van de Peer, Y. and De Wachter, R. 1997. Construction of evolutionary distance trees with TREECON for Windows: accounting for variation in nucleotide substitution rate among sites. Computer Applications in Biosciences 13: 227-230.

Vos, P., Bleeker, M., Reijans, M. 1995. AFLP: a new technique for DNA fingerprinting. Nucleic Acids Research 23: 4407-14.

Wang, M., Yu, X. and Liu, Y. 2006. Genetic analysis of isozyme in Pteria penguin $R$. and offspring from inbreeding and hybridized stocks of Pinctada martensii D. Chinese Journal of Agricultural Biotechnology 3 : 127-133.

Zeller, K.A., Jurgenson, J.E., El-Assiuty E.M. 2000. Isozyme and AFLP from Cephalosporium maydis in Egypt. Phytoparasitica 28: 121-30. 
تقدير درجـة التباين الـوراثي بين ستة محاصيل مصرية للعلف بإستخدام التقتية

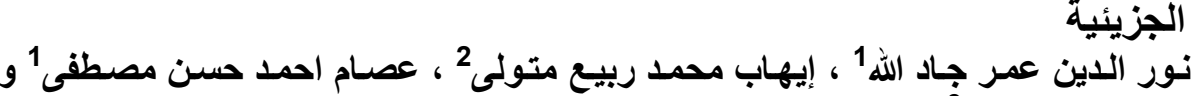

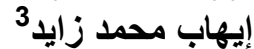

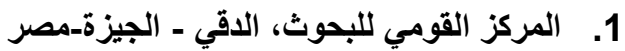

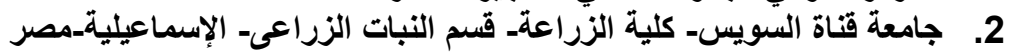

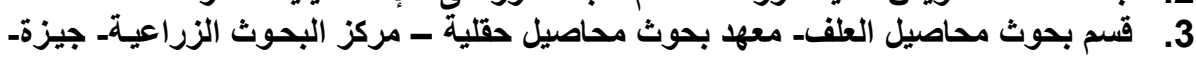

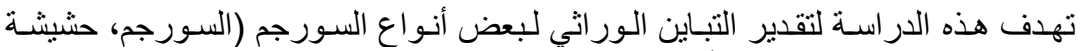

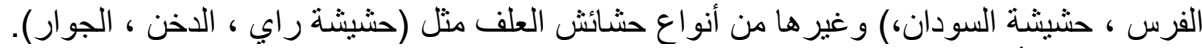

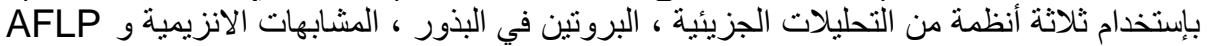

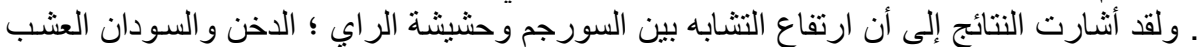

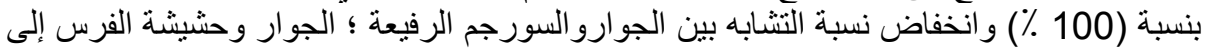
(44.4) في تحليل البيروكسيديز.

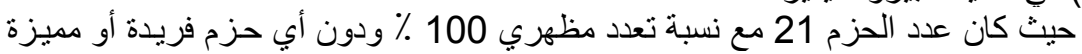
superoxidase من نوعها. وكانت هذه البيانات غير متو افقة مع نتائج تحليل إنزيم ديسمونت

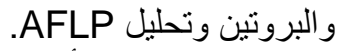

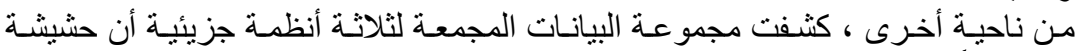

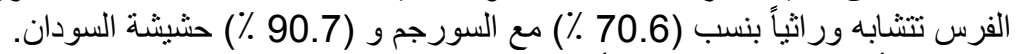

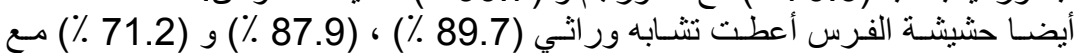

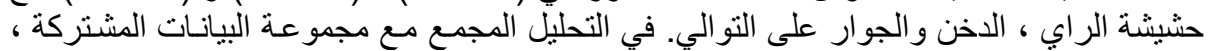

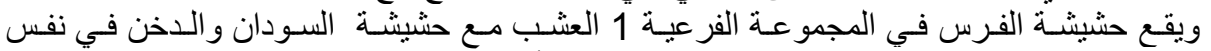

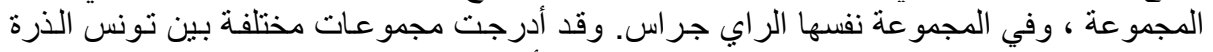

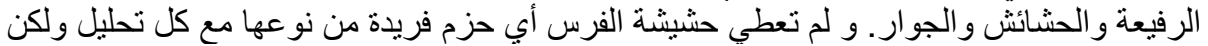

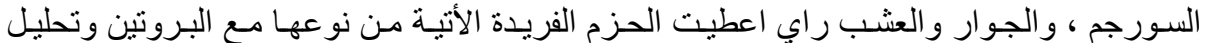

AFLP

كلية الزراعة - جامعة المنصورة كلية الزراعة بالاسماعيليه - جامعة قناة السويس النداء
قام بتحكيم البحث

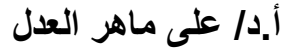
أ.د/ عبد الرحيم احمد عبد الرحيم النجار 